Check for updates

Cite this: RSC Adv., 2019, 9, 16730

Received 25th April 2019

Accepted 21st May 2019

DOI: $10.1039 / \mathrm{c} 9 \mathrm{ra03084k}$

rsc.li/rsc-advances

\section{Electrodeposition of amorphous $\mathrm{WO}_{3}$ on $\mathrm{SnO}_{2}-$ $\mathrm{TiO}_{2}$ inverse opal nano-framework for highly transparent, effective and stable electrochromic smart window $\dagger$}

\author{
Tam Duy Nguyen, ${ }^{\star a b}$ Loo Pin Yeo, ${ }^{\text {ab }}$ Daniel Mandler, (DD bc Shlomo Magdassi ${ }^{\text {bc }}{ }^{\text {bc }}$ \\ and Alfred ling Yoong Tok (D) *ab
}

In recent years, there has been significant advancement in smart window technologies due to their effectiveness in reducing energy consumption of indoor lighting and air-conditioning in buildings. Electrochromic (EC) materials, in particular, have been widely studied as they provide a simple method for tuning or modulating visible light and infrared (IR) transmittance. In this work, a novel hybrid, multilayered $\mathrm{SnO}_{2}-\mathrm{TiO}_{2}-\mathrm{WO}_{3}$ inverse opal (IO) nanostructure has been fabricated via dip-coating and electrodeposition process. This hybrid nanostructure allows an electrochromic smart window for effective near infrared (NIR) modulation, with high visible transparency and durable EC cycling stability. The visible transparency of as-fabricated hybrid multi-layered $\mathrm{SnO}_{2}-\mathrm{TiO}_{2}-\mathrm{WO}_{3} 1 \mathrm{O}$ was measured to be in the range of $67.2-88.0 \%$ in the bleached state and $67.0-74.4 \%$ in the colored state, respectively. Furthermore, the hybrid nanostructure is also able to modulate up to $63.6 \%$ NIR radiation at the wavelength of $1200 \mathrm{~nm}$ and maintain approximately $82.6 \%$ of its NIR blockage capability after 750 reversible cycles. The hybrid multi-layered $\mathrm{SnO}_{2}-\mathrm{TiO}_{2}-\mathrm{WO}_{3} \mathrm{IO}$ nanostructure in this study can potentially be an effective and stable EC material for advanced smart window technology.

\section{Introduction}

Electrochromic (EC) materials are defined by their ability to change their optical properties reversibly through the application of an electrical current or voltage., ${ }^{1,2}$ Many promising applications that have been proposed, e.g. smart glass, electrochromic mirrors, and electrochromic display devices, rely on the phenomenon of electrochromism. EC smart window technology, which is able to electrically modulate the transmittance of solar radiation, is one of the most widely investigated methods to assist in the reduction of energy consumption in indoor lighting and air-conditioning. ${ }^{3}$ This is especially relevant now as more high-rise buildings, are placing enormous strains on energy demands for indoor cooling and heating. Amongst the various EC materials, transition metal oxide $\mathrm{WO}_{3}$ is one of the earliest studied materials and still possesses the best EC performance to date. ${ }^{1}$ Upon the electrochemical insertion/

${ }^{a}$ School of Materials Science and Engineering, Nanyang Technological University, 50 Nanyang Avenue, Singapore 639798.E-mail: tamnguyen@ntu.edu.sg; MIYTok@ntu. edu

${ }^{b}$ Singapore-HUJ Alliance for Research and Enterprise, NEW-CREATE Phase II, Campus for Research Excellence and Technological Enterprise (CREATE), Singapore 138602 'Institute of Chemistry, The Hebrew University of Jerusalem, Jerusalem 9190401, Israel $\dagger$ Electronic supplementary information (ESI) available: Additional characterization data. See DOI: 10.1039/c9ra03084k extraction of small cations such as $\mathrm{H}^{+}$or $\mathrm{Li}^{+}, \mathrm{WO}_{3}$ exhibits corresponding reversible changes in optical property (colored/ bleached) (eqn (1), M = H, Li,...): $:^{4-8}$

$$
\left[\mathrm{WO}_{3}+\mathrm{M}^{+}+\mathrm{e}^{-}\right]_{\text {bleached }} \leftrightarrow\left[\mathrm{MWO}_{3}\right]_{\text {colored }}
$$

Various material structures and designs have been investigated to improve the overall EC performance of $\mathrm{WO}_{3}$, such as nanoparticles, ${ }^{9-15}$ thin films, ${ }^{16-26}$ nanorods ${ }^{27-29}$ etc. The crystal structure of $\mathrm{WO}_{3}$ is also another factor affecting the performance, with many studies reporting that amorphous $\mathrm{WO}_{3}$ has better EC efficiency than its crystalline form due to higher ion storage capacity at the same applied voltage. ${ }^{30-34}$ Recently, a modification technique based on three-dimensional inverse opal (IO) structures has been widely used to improve the overall performance of $\mathrm{WO}_{3}$ EC material, owing to an enhancement in light absorption with its continuous and periodic structure. In addition, its large specific surface area also increases the active area and improves charge transfer kinetics during redox reactions. ${ }^{35-41}$

Since the high visible transparency is one of the fundamental properties of glass window, it is necessary to shift the radiation modulation to the IR (or NIR) range. On the other hand, the IR (or NIR) modulation is also found to be more effective for the heat management in the field of smart window, as nearly $50 \%$ of 
solar energy comes from IR radiation. However, many studies on $\mathrm{WO}_{3}$ EC materials have achieved a large IR (or NIR) modulation, but have failed to get high visible transparency especially in the colored state. For example, Zhou et al. reported $\mathrm{Ag} / \mathrm{WO}_{3}$ nanowires which enable approximately 59\% NIR modulation at $1100 \mathrm{~nm}$, and approximately $57.1 \%$ transparency at $500 \mathrm{~nm} .^{26}$ The bilayer $\mathrm{WO}_{3}$ IO structure synthesized by Li et al. showed $57.6 \%$ NIR modulation at $1100 \mathrm{~nm}$, but only $27.3 \%$ transparency at $500 \mathrm{~nm} .{ }^{40}$ The hybrid $\mathrm{TiO}_{2}-\mathrm{WO}_{3}$ IO structure synthesized by Ling et al. also achieved about $62.5 \%$ NIR modulation at $1100 \mathrm{~nm}$, but only $22.7 \%$ transparency at $500 \mathrm{~nm} .{ }^{41}$ The second issue that the $\mathrm{WO}_{3}$-based smart window system needs to overcome is the low device lifespan. Long-term EC performance of $\mathrm{WO}_{3}$ materials is found to be suffered from degradation due to the accumulation of trapped ions in the host structure. $^{42-47}$ To improve the stability, many modification methods have been reported, including tuning of the fabrication process, ${ }^{48}$ optimizing periodicity and degree of crystallinity, ${ }^{49}$ and varying of the film thickness. ${ }^{50}$ Wen et al. reported that ion-trapping-induced degradation, which is commonly believed to be irreversible, can be successfully eliminated by constant current-driven de-trapping. ${ }^{51}$ However, doping or compositing with metal cations or metal oxides, e.g. $\mathrm{Nb},{ }^{52} \mathrm{Mo},{ }^{53}$ and most commonly with $\mathrm{Ti}^{41,54-60}$ are the most effective methods to improve EC cycle stability of $\mathrm{WO}_{3}$. Overall, it is still a challenge to develop an optimal material structure and design that can satisfy all requested features of a modern smart window technology, e.g. high visible transparency, effective NIR modulation and long-term EC stability.

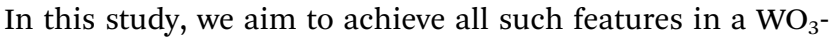
based nanostructure using double-layered $\mathrm{SnO}_{2}-\mathrm{TiO}_{2}$ IO framework to produce a multi-layered structure. The polystyrene (PS) opal was used as the initial template to fabricate the $\mathrm{SnO}_{2}$ and $\mathrm{SnO}_{2}-\mathrm{TiO}_{2}$ IO framework, after which the electrodeposition method was employed to obtain the hybrid multilayered $\mathrm{SnO}_{2}-\mathrm{TiO}_{2}-\mathrm{WO}_{3} \mathrm{IO}$ nanostructures. The morphology, crystal structure and surface chemistry of the as-fabricated multi-layered $\mathrm{SnO}_{2}-\mathrm{TiO}_{2}-\mathrm{WO}_{3}$ IO nanostructures were characterized by Field Emission Scanning Electron Microscopy (FESEM), X-ray diffraction (XRD), Scanning Transmission Electron Microscopy (STEM) coupled with energy-dispersive Xray spectroscopy (EDX), and X-ray photoelectron spectrometer (XPS), respectively. The optical properties and NIR modulation performance of hybrid multi-layered $\mathrm{SnO}_{2}-\mathrm{TiO}_{2}-\mathrm{WO}_{3}$ IO nanostructures were examined by Ultraviolet-Visible-NIR (UVVis-NIR) spectroscopy under constant potential supply. It was found that the addition of an ultra-thin $\mathrm{TiO}_{2}$ layer on $\mathrm{SnO}_{2} \mathrm{IO}$ framework could effectively improve the long-term EC cycling stability of $\mathrm{SnO}_{2}-\mathrm{TiO}_{2}-\mathrm{WO}_{3}$ IO nanostructure, while maintaining the effective NIR modulation and high visible transparency in both the colored and bleached states. This study introduces a novel EC material structure for stable and effective NIR-active smart window applications.

\section{Experimental}

\section{Synthesis of hybrid multi-layered $\mathrm{SnO}_{2}-\mathrm{TiO}_{2}-\mathrm{WO}_{3}$ inverse opal}

Fig. $\mathrm{S} 1 \dagger$ illustrates the fabrication procedure of hybrid multilayered $\mathrm{SnO}_{2}-\mathrm{TiO}_{2}-\mathrm{WO}_{3}$ IO nanostructure. Mono-dispersed polystyrene (PS) spheres (Thermo Fisher Scientific) were diluted in DI water and sonicated for $30 \mathrm{~min}$. Clean FTO glasses $\left(1.5 \times 2.5 \mathrm{~cm}^{2}\right)$ were immersed in the PS dispersion horizontally at $60{ }^{\circ} \mathrm{C}$ for 3 days to achieve a self-assembled PS opal template on the FTO glass substrate. In this work, two initial PS opal sizes were used in the fabrication process (392 and $520 \mathrm{~nm}$ ).

The $\mathrm{SnO}_{2}$ IO was obtained by dip-coating the PS opal template in an aqueous $\mathrm{SnO}_{2}$ precursor. ${ }^{61}$ The precursor solution was prepared by mixing $15 \mathrm{~mL}$ of ethylene glycol (EG) (Sigma-Aldrich) and $3 \mathrm{mmol}$ of $\mathrm{SnCl}_{4} \cdot 5 \mathrm{H}_{2} \mathrm{O}$ (Sigma-Aldrich) in a glass beaker under continuous stirring, then heated up to $120{ }^{\circ} \mathrm{C}$ for $1 \mathrm{~h}$. After cooling of the mixture, $35 \mathrm{~mL}$ of ethanol (Sigma-Aldrich) was added into the solution to reduce the viscosity. The PS opal template was dipped twice into the resultant solution under vacuum for $3 \mathrm{~min}$ each time and left to dry at $60{ }^{\circ} \mathrm{C}$ for $20 \mathrm{~min}$. Vacuum dipping, in this case, assisted the infiltration of the precursor into the PS opal structure. This was followed by calcination at $500{ }^{\circ} \mathrm{C}$ for $2 \mathrm{~h}$ (ramping rate $1{ }^{\circ} \mathrm{C} \mathrm{min}{ }^{-1}$ ) to obtain the $\mathrm{SnO}_{2}$ IO. Similarly, a thin $\mathrm{TiO}_{2}$ layer was deposited onto the $\mathrm{SnO}_{2}$ IO surface by dipping into the $\mathrm{TiO}_{2}$ precursor. The standard recipe of the $\mathrm{TiO}_{2}$ precursor solution for the dip-coating process was prepared by mixing $1 \mathrm{~mL}$ of titanium tetra-butoxide (Sigma-Aldrich), $0.4 \mathrm{~mL}$ of hydrochloric acid (37\%, Sigma-Aldrich), $16 \mathrm{~mL}$ of ethanol (Sigma-Aldrich), and $10 \mathrm{~mL}$ of DI water, respectively. The $\mathrm{SnO}_{2}$ IO framework was vacuum-dipped into the precursor solution once for 45 seconds and then dried at $60{ }^{\circ} \mathrm{C}$ for $20 \mathrm{~min}$. The dip-coated samples were heated at $500{ }^{\circ} \mathrm{C}$ for 2 hours at a heating rate of $1{ }^{\circ} \mathrm{C} \min ^{-1}$ to obtain the double-layered $\mathrm{SnO}_{2}-\mathrm{TiO}_{2}$ IO framework.

Finally, $\mathrm{WO}_{3}$ electrodeposition was carried out on the $\mathrm{SnO}_{2}-$ $\mathrm{TiO}_{2}$ IO structure to fabricate the hybrid multi-layered $\mathrm{SnO}_{2}-$ $\mathrm{TiO}_{2}-\mathrm{WO}_{3}$ IO nanostructure. The $\mathrm{WO}_{3}$ precursor solution was prepared by mixing $1.03 \mathrm{~g}$ of $\mathrm{Na}_{2} \mathrm{WO}_{4} \cdot 2 \mathrm{H}_{2} \mathrm{O}$ (Sigma-Aldrich) and $0.65 \mathrm{~mL}$ of $\mathrm{H}_{2} \mathrm{O}_{2}$ (Sigma-Aldrich) in $250 \mathrm{~mL}$ of DI water. After that, $2 \mathrm{~mL}$ of $\mathrm{HClO}_{4}$ (Sigma-Aldrich) was gradually added into the solution until the $\mathrm{pH}$ reached the value of $1.2 .^{62}$ The electrodeposition process was conducted at a constant potential of $-0.7 \mathrm{~V}$ for 200 seconds. $\mathrm{SnO}_{2}-\mathrm{WO}_{3}$ and $\mathrm{TiO}_{2}-\mathrm{WO}_{3}$ IO nanostructures were also prepared as the references using the same parameters. The obtained samples were rinsed with DI water and dried with nitrogen gas.

\section{Characterization}

The morphologies of the obtained samples were characterized by FESEM (JEOL 7600F). The crystal structure of $\mathrm{SnO}_{2}-\mathrm{TiO}_{2}-$ $\mathrm{WO}_{3} \mathrm{IO}$ was characterized by an X-ray diffractometer (Shimadzu $\mathrm{XRD}-6000$, with the $\lambda \mathrm{Cu}-\mathrm{K} \alpha=0.15418 \mathrm{~nm})$. The atomic compositions and core-shell structure were identified by a STEM (JEOL 2100F STEM equipped with INCA EDS detector). 
The surface chemistry is characterized by a Kratos AXIS Supra Xray photoelectron spectrometer.

The spectro-electrochemical properties of obtained samples were measured using a Solartron potentiostat (Model 1470E) and a UV-Vis-NIR spectrophotometer (Shimadzu UV 3600). The UV-Vis spectra of all samples were recorded in the wavelength range of 300 to $1600 \mathrm{~nm}$ at potentials of -0.3 and $+0.8 \mathrm{~V}$. The dynamic optical transmittance was also recorded for the $\mathrm{SnO}_{2}-$ $\mathrm{TiO}_{2}-\mathrm{WO}_{3}$ IO samples in the wavelength range of interest under repeating square wave potentials oscillating between +0.8 and $-0.3 \mathrm{~V}$ at a time step of $120 \mathrm{~s}$ and $80 \mathrm{~s}$ respectively. It was recorded for more than 750 reversible cycles to characterize its long-term stability.

\section{Results and discussion}

\section{Morphology, crystal structure and surface chemistry}

Fig. 1 shows the FESEM images of as-synthesized $\mathrm{SnO}_{2}, \mathrm{SnO}_{2}-$ $\mathrm{TiO}_{2}$ and hybrid multi-layered $\mathrm{SnO}_{2}-\mathrm{TiO}_{2}-\mathrm{WO}_{3}$ IO nanostructure with initial PS opal size of $392 \mathrm{~nm}$. The $\mathrm{SnO}_{2} \mathrm{IO}$ framework (Fig. 1a) is homogenously fabricated after the removal of PS template. The diameter of the $\mathrm{SnO}_{2}$ IO pores is approximately $250 \mathrm{~nm}$, which is smaller than that of the initial PS opal diameter $(392 \mathrm{~nm})$ due to shrinkage in the $\mathrm{SnO}_{2}$ framework following the calcination process at $500{ }^{\circ} \mathrm{C}$. The $\mathrm{SnO}_{2}$ IO framework is arranged in a hexagonal array and the openings that connect the adjacent pores can be clearly observed. The distance between two adjacent pores is measured to be approximately $260 \mathrm{~nm}$. With the coating of a thin layer of $\mathrm{TiO}_{2}$, there is no significant change in the morphology of the

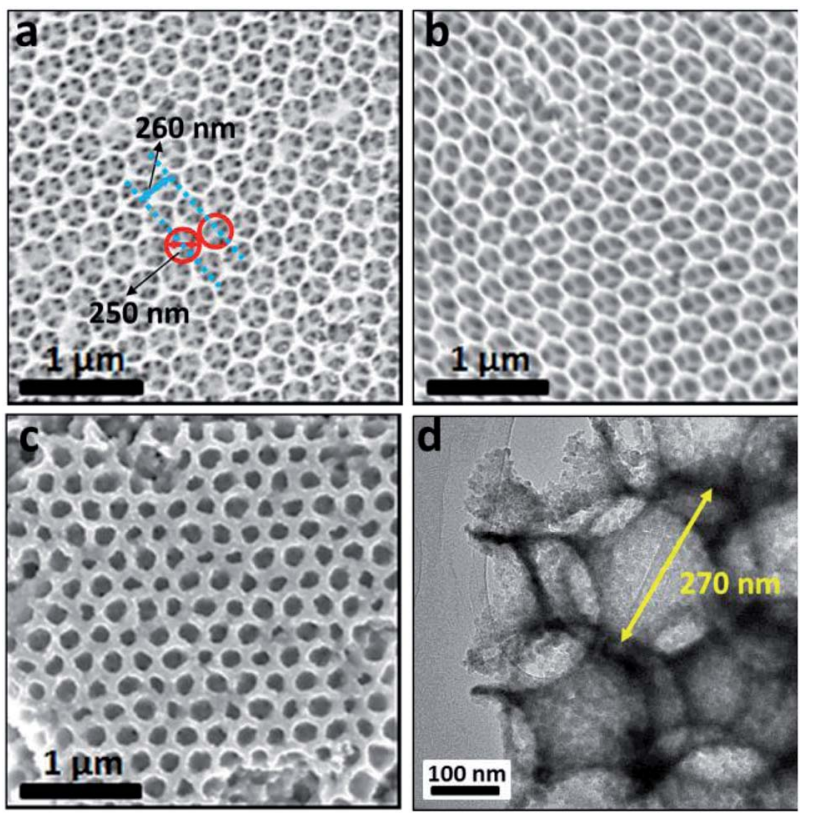

Fig. 1 FESEM images of $\mathrm{SnO}_{2} \mathrm{IO}(\mathrm{a}), \mathrm{SnO}_{2}-\mathrm{TiO}_{2} \mathrm{IO}$ (b), and hybrid multi-layered $\mathrm{SnO}_{2}-\mathrm{TiO}_{2}-\mathrm{WO}_{3} \mathrm{IO}$ nanostructure (c) with initial poresize of $392 \mathrm{~nm}$ and electro-deposition duration of 200 seconds. All images were acquired under the same magnification. (d) HRTEM image of hybrid multi-layered $\mathrm{SnO}_{2}-\mathrm{TiO}_{2}-\mathrm{WO}_{3} \mathrm{IO}$ nanostructure. double-layered $\mathrm{SnO}_{2}-\mathrm{TiO}_{2}$ IO framework (Fig. 1b). However, following $\mathrm{WO}_{3}$ electrodeposition, a uniformly deposited $\mathrm{WO}_{3}$ layer can be clearly observed on the surface of the doublelayered $\mathrm{SnO}_{2}-\mathrm{TiO}_{2}$ IO framework (Fig. 1c), forming a hybrid multi-layered $\mathrm{SnO}_{2}-\mathrm{TiO}_{2}-\mathrm{WO}_{3}$ IO nanostructure. The HRTEM image also confirms the inverse opal structure of as-fabricated $\mathrm{SnO}_{2}-\mathrm{TiO}_{2}-\mathrm{WO}_{3}$ nanostructures, with the void space of $\mathrm{SnO}_{2}$ framework approximated at $270 \mathrm{~nm}$ (Fig. 1d). Samples fabricated from $520 \mathrm{~nm}$ initial PS opal template have similar morphologies to the $392 \mathrm{~nm}$ samples, except with bigger void space dimensions (Fig. S2†).

Fig. 2 shows the XRD patterns of FTO substrate, $\mathrm{SnO}_{2} \mathrm{IO}$, $\mathrm{TiO}_{2} \mathrm{IO}$ and hybrid multi-layered $\mathrm{SnO}_{2}-\mathrm{TiO}_{2}-\mathrm{WO}_{3}$ IO samples. It is observed that both FTO substrate and $\mathrm{SnO}_{2}$ IO exhibit characteristic diffraction peaks at $2 \theta=26.7,33.8,38.0,51.7$, $55.0,61.7,66.1,78.7^{\circ}$, which correspond to the planes of $(110)$, (101), (200), (211), (220), (310), (301) and (321) of $\mathrm{SnO}_{2}$ (ICDD 01070-4176), respectively. There is a dissimilarity in the (200) plane peak intensity of both samples, which may be due to the different preferred crystal orientation in $\mathrm{SnO}_{2}$ IO structure as compared to the bare FTO glass. The XRD pattern of $\mathrm{TiO}_{2} \mathrm{IO}$ indicates the formation of anatase $\mathrm{TiO}_{2}$, with characteristic diffraction peaks at $2 \theta=25.4,37.9,48.1,54.0,62.8^{\circ}$, corresponding to the planes of (101), (004), (200), (105), and (211) of $\mathrm{TiO}_{2}$ (ICDD 96-101-0943), respectively. The XRD pattern of multi-layered $\mathrm{SnO}_{2}-\mathrm{TiO}_{2}-\mathrm{WO}_{3} \mathrm{IO}$ shows only the formation of $\mathrm{SnO}_{2}$ and $\mathrm{TiO}_{2}$ crystal with a lack of distinct $\mathrm{WO}_{3}$ peaks, which implies the amorphous nature of the electrodeposited $\mathrm{WO}_{3}$ layer.

The STEM image coupled with EDX mapping, as shown in Fig. 3a, reveals the multi-layered structure of as-fabricated $\mathrm{SnO}_{2}-\mathrm{TiO}_{2}-\mathrm{WO}_{3}$ IO. The distribution of $\mathrm{SnO}_{2}, \mathrm{TiO}_{2}$ and $\mathrm{WO}_{3}$ layers can be observed in the multi-layered IO nanostructure mapping, which clearly shows that the inner $\mathrm{SnO}_{2}-\mathrm{TiO}_{2}$ framework is surrounded by a layer of amorphous $\mathrm{WO}_{3}$. As shown in Fig. 3b, the bulk elemental composition of asfabricated $\mathrm{SnO}_{2}-\mathrm{TiO}_{2}-\mathrm{WO}_{3}$ IO is measured to be 53.9, 5.0 and 41.1 at $\%$ for $\mathrm{Sn}, \mathrm{Ti}$ and $\mathrm{W}$, respectively. This indicates that the

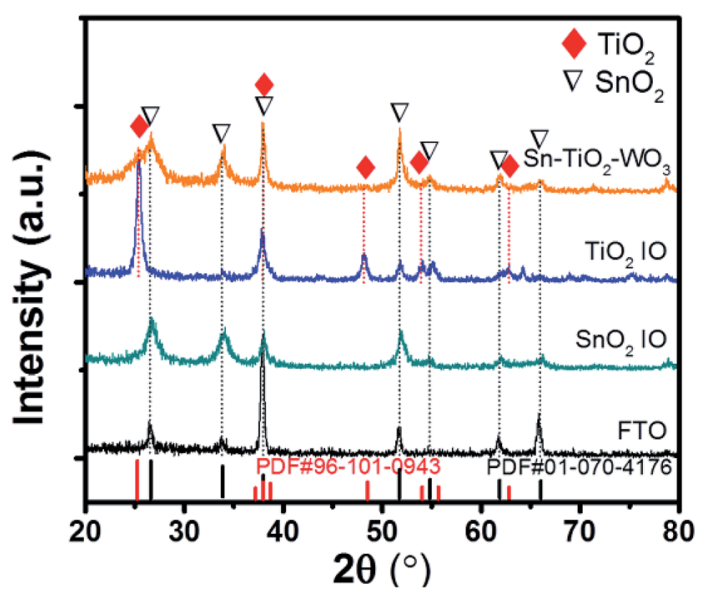

Fig. 2 XRD patterns of FTO, $\mathrm{SnO}_{2} \mathrm{IO}, \mathrm{TiO}_{2} \mathrm{IO}$ and hybrid multi-layered $\mathrm{SnO}_{2}-\mathrm{TiO}_{2}-\mathrm{WO}_{3} \mathrm{IO}$ nanostructure. 


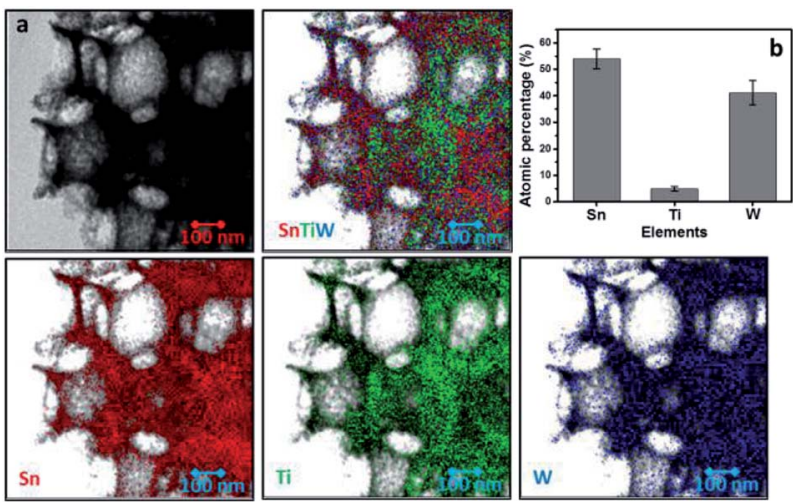

Fig. 3 STEM images coupled with EDX mapping of hybrid multilayered $\mathrm{SnO}_{2}-\mathrm{TiO}_{2}-\mathrm{WO}_{3} 1 \mathrm{O}$ nanostructure (a) and bulk elemental composition obtained from EDX analysis.

thickness of the $\mathrm{TiO}_{2}$ layer is very thin as compared to the $\mathrm{SnO}_{2}$ and $\mathrm{WO}_{3}$ layers.

The surface chemistry of hybrid multi-layered $\mathrm{SnO}_{2}-\mathrm{TiO}_{2}-$ $\mathrm{WO}_{3} \mathrm{IO}$ nanostructure is characterized by XPS measurement. Fig. 4 presents the wide scan XPS spectra and surface elemental compositions of $\mathrm{SnO}_{2}-\mathrm{WO}_{3}, \mathrm{TiO}_{2}-\mathrm{WO}_{3}$ and hybrid multilayered $\mathrm{SnO}_{2}-\mathrm{TiO}_{2}-\mathrm{WO}_{3}$ IO nanostructures. The wide scan spectra (Fig. 4a) demonstrate the presence of $01 \mathrm{~s}$, W4f and Sn3d peaks in all samples, while the peak of Ti2p is negligible due to the low content of $\mathrm{TiO}_{2}$ as mentioned in the above EDX bulk analysis. By quantification analysis, the surface elemental composition of $\mathrm{SnO}_{2}-\mathrm{WO}_{3} \mathrm{IO}$ is composed of approximately 1.3, 25.4 and 73.3 at $\%$ of $\mathrm{Sn}, \mathrm{W}$ and $\mathrm{O}$, respectively. For $\mathrm{TiO}_{2}-\mathrm{WO}_{3}$ IO, this value is $0.8,27.2$ and 72.0 at $\%$ for $\mathrm{Ti}, \mathrm{W}$ and $\mathrm{O}$, respectively. For hybrid multi-layered $\mathrm{SnO}_{2}-\mathrm{TiO}_{2}-\mathrm{WO}_{3} \mathrm{IO}$, it is measured to be about $0.1,0.3,17.2$ and 82.4 at $\%$ for Sn, Ti, W and $\mathrm{O}$, respectively. The higher amount of $\mathrm{W}$ as compared to $\mathrm{Sn}$ and $\mathrm{Ti}$ reveals the dominance of $\mathrm{WO}_{3}$ layer on the surface of hybrid multi-layered $\mathrm{SnO}_{2}-\mathrm{TiO}_{2}-\mathrm{WO}_{3}$ IO. The bulk EDX analysis, however, shows that the amount of $\mathrm{W}(41.1$ at\%) and $\operatorname{Ti}(5$ at\%) is much lower than $\mathrm{Sn}(53.9$ at\%) in the hybrid multilayered $\mathrm{SnO}_{2}-\mathrm{TiO}_{2}-\mathrm{WO}_{3}$ IO. The results of both analyses correspond well with the expected arrangement in the multilayered structure of hybrid $\mathrm{SnO}_{2}-\mathrm{TiO}_{2}-\mathrm{WO}_{3} \mathrm{IO}$.

Fig. 5 presents the fine scan XPS spectra of O1s, W4f, Ti2p and $\mathrm{Sn} 3 \mathrm{~d}$ components of hybrid multi-layered $\mathrm{SnO}_{2}-\mathrm{TiO}_{2}-\mathrm{WO}_{3}$ IO. By curve-fitting analysis, the O1s spectrum of hybrid $\mathrm{SnO}_{2}-$ $\mathrm{TiO}_{2}-\mathrm{WO}_{3} \mathrm{IO}$ is located in the metal oxide binding energy range $(\sim 530.8 \mathrm{eV})$. The $\mathrm{W} 4 \mathrm{f}$ spectrum is located at the binding energy of approximately $36.0 \mathrm{eV}$, confirming the $\mathrm{WO}_{3}$ chemical state, with well separated spin-orbit components $\left(\Delta_{\text {metal }}=2.17 \mathrm{eV}\right)$. The Ti2p spectrum also confirms the $\mathrm{TiO}_{2}$ chemical state $(\sim 459.1 \mathrm{eV})$. The fine scan XPS spectra of $\mathrm{SnO}_{2}-\mathrm{WO}_{3}$ and $\mathrm{TiO}_{2}{ }^{-}$ $\mathrm{WO}_{3}$ IO nanostructure can also be found in the ESI (Fig. S4).†
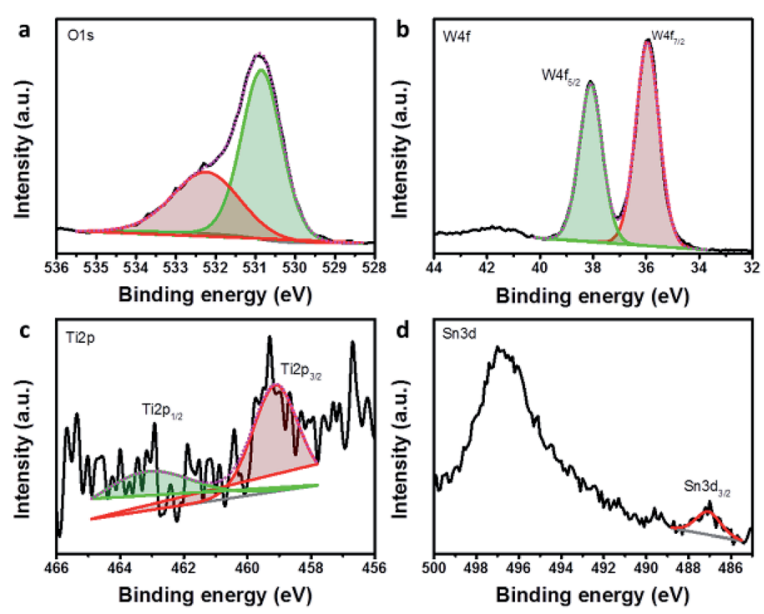

Fig. 5 The fine XPS spectra of O1s (a), W4f (b), Ti2p (c), and Sn3d (d) components of hybrid multi-layered $\mathrm{SnO}_{2}-\mathrm{TiO}_{2}-\mathrm{WO}_{3} \quad 10$ nanostructure.
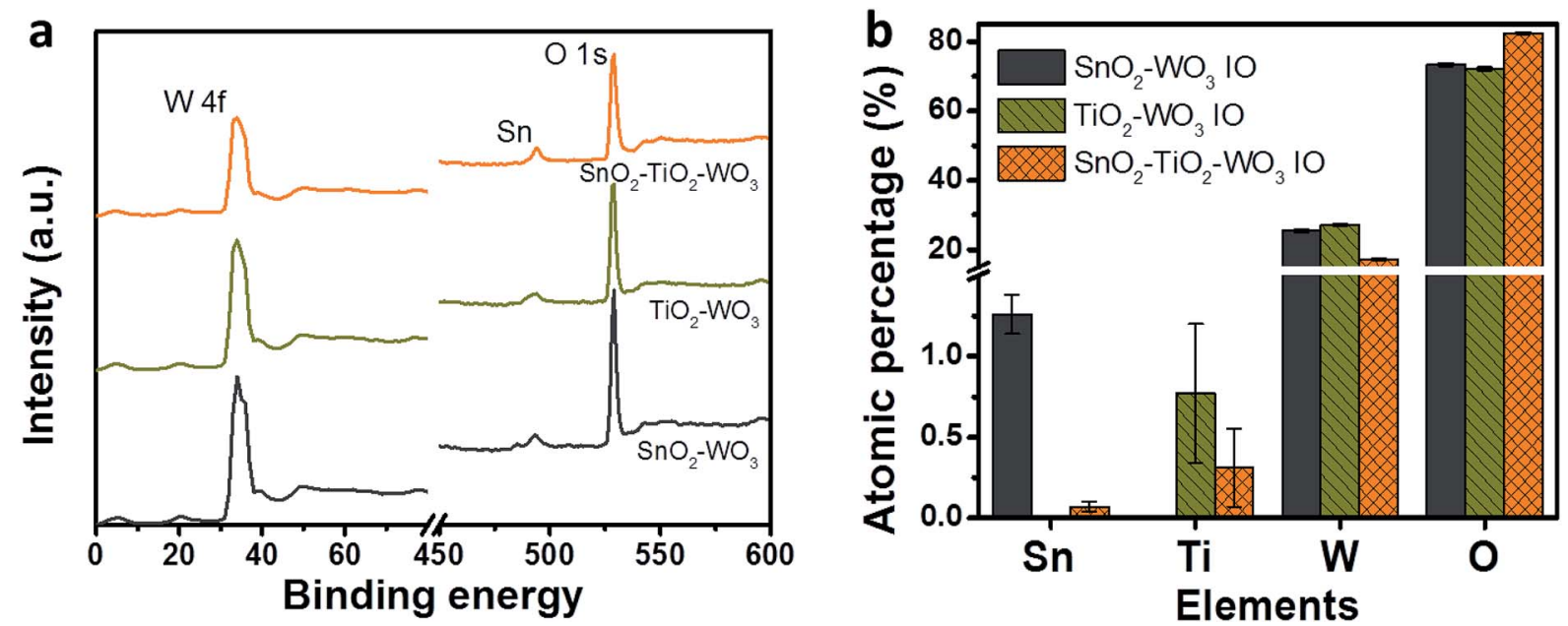

Fig. 4 Wide scan XPS spectra (a) and surface elemental composition (b) of $\mathrm{SnO}_{2}-\mathrm{WO}_{3}, \mathrm{TiO}_{2}-\mathrm{WO}_{3}$, and hybrid multi-layered $\mathrm{SnO}_{2}-\mathrm{TiO} 2-\mathrm{WO}_{3}$ 10 nanostructure. 


\section{Optical properties and NIR modulation performance}

Since FTO glass allows less than $30 \%$ IR transmittance beyond $1600 \mathrm{~nm}$, this work will focus only on the NIR modulation within the range of 700-1600 $\mathrm{nm}$, while the visible transparency is examined between $300-700 \mathrm{~nm} \cdot{ }^{41,61}$ Fig. 6 shows the UV-Vis spectra of $\mathrm{SnO}_{2}-\mathrm{WO}_{3}, \mathrm{TiO}_{2}-\mathrm{WO}_{3}$ and hybrid multi-layered $\mathrm{SnO}_{2}-\mathrm{TiO}_{2}-\mathrm{WO}_{3}$ IO recorded at constant potentials of $+0.8 \mathrm{~V}$ and $-0.3 \mathrm{~V}$ from 300 to $1600 \mathrm{~nm}$ in $0.1 \mathrm{M} \mathrm{LiClO}_{4} / \mathrm{PC}$ electrolyte. It has been reported that the $\mathrm{WO}_{3}$ IO structure has much higher electrochromic performance than that of $\mathrm{WO}_{3}$ thin film. ${ }^{\mathbf{4 1 , 6 1}}$ Therefore, in this work, only IO structures obtained from initial PS sizes of 392 (Fig. 6a) and $520 \mathrm{~nm}$ (Fig. 6b) are characterized. In the bleached state, all IO samples demonstrate high transmittance in both NIR and visible regions. Upon applying a negative voltage in the colored state $(-0.3 \mathrm{~V})$, all samples show a significant reduction in NIR transmittance while maintaining highly transparent in the visible region. The ability to modulate NIR transmittance over a wide range while remaining transparent satisfies the desired optical properties of hybrid multilayered $\mathrm{SnO}_{2}-\mathrm{TiO}_{2}-\mathrm{WO}_{3} \mathrm{IO}$ for smart window applications. For both tested pore sizes, the visible transparency of hybrid multi-layered $\mathrm{SnO}_{2}-\mathrm{TiO}_{2}-\mathrm{WO}_{3}$ IO is mostly similar to $\mathrm{SnO}_{2}-$ $\mathrm{WO}_{3} \mathrm{IO}$, and significantly higher than that of $\mathrm{TiO}_{2}-\mathrm{WO}_{3} \mathrm{IO}$.

The detailed electrochromic performance of $\mathrm{SnO}_{2}-\mathrm{WO}_{3}$, $\mathrm{TiO}_{2}-\mathrm{WO}_{3}$ and hybrid multi-layered $\mathrm{SnO}_{2}-\mathrm{TiO}_{2}-\mathrm{WO}_{3}$ IO nanostructures are presented in the UV-Vis spectra in Fig. 7. Data at several wavelengths were specifically selected for better comparison of the modulation effect: 400, 500, $600 \mathrm{~nm}$ (Fig. 7a and b) in the visible region and 800, 1200, $1600 \mathrm{~nm}$ (Fig. 7c and d) in the NIR region. In Fig. 7a, $392 \mathrm{~nm} \mathrm{SnO}{ }_{2}-\mathrm{WO}_{3}$ IO indicates a visible transparency of $70.8-89.8 \%$ during the bleached state and $62.2-70.0 \%$ during the colored state. The transparency of $392 \mathrm{~nm} \mathrm{TiO}_{2}-\mathrm{WO}_{3}$ IO is lower at 54.6-78.2\% during the bleached state and only $52.8-56.7 \%$ during the colored state. The hybrid multi-layered $\mathrm{SnO}_{2}-\mathrm{TiO}_{2}-\mathrm{WO}_{3}$ IO shows a similar transparency as $\mathrm{SnO}_{2}-\mathrm{WO}_{3}$ IO: $67.2-88.0 \%$ in the bleached and $67.0-74.4 \%$ in the colored states. The same trend of visible transparency was observed for all samples of $520 \mathrm{~nm}$ initial PS
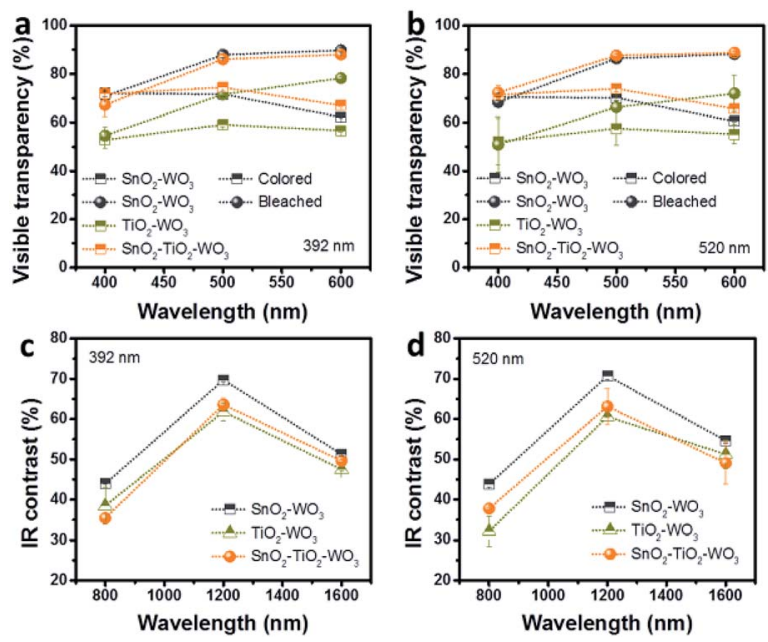

Fig. 7 Visible transparency ( $a$ and b) and NIR contrast (c and d) between colored and bleached state of $\mathrm{SnO}_{2}-\mathrm{WO}_{3}, \mathrm{TiO}_{2}-\mathrm{WO}_{3}$, and hybrid multi-layered $\mathrm{SnO}_{2}-\mathrm{TiO}_{2}-\mathrm{WO}_{3} \mathrm{IO}$ nanostructure

opal size (Fig. 7b). In comparison with other research, the visible transparency of as-fabricated hybrid multi-layered $\mathrm{SnO}_{2}-$ $\mathrm{TiO}_{2}-\mathrm{WO}_{3}$ IO nanostructure is found to be much higher, especially in the colored state. Zhou et al. reported $\mathrm{Ag} / \mathrm{WO}_{3}$ nanowires with approximately $57.1 \%$ transparency at $500 \mathrm{~nm} .^{26}$ The bilayer $\mathrm{WO}_{3}$ IO structure synthesized by Li et al. showed only $27.3 \%$ transparency at $500 \mathrm{~nm} .{ }^{40}$ The hybrid $\mathrm{TiO}_{2}-\mathrm{WO}_{3}$ IO structure synthesized by Ling et al. also achieved only $22.7 \%$ transparency at $500 \mathrm{~nm} .^{\mathbf{4 1}}$ This significant improvement in visible light transparency is due to the excellent optical transparency of the $\mathrm{SnO}_{2}$ framework as compared to $\mathrm{TiO}_{2}$.

The NIR contrast between the bleached and colored states of $\mathrm{SnO}_{2}-\mathrm{WO}_{3}, \mathrm{TiO}_{2}-\mathrm{WO}_{3}$ and hybrid multi-layered $\mathrm{SnO}_{2}-\mathrm{TiO}_{2}-$ $\mathrm{WO}_{3}$ IO nanostructures is presented in Fig. 7c and d. In general, the $\mathrm{SnO}_{2}-\mathrm{WO}_{3}$ IO demonstrates the highest NIR modulation capability, while the hybrid multi-layered $\mathrm{SnO}_{2}-\mathrm{TiO}_{2}-\mathrm{WO}_{3} \mathrm{IO}$ reveals better NIR modulation than the $\mathrm{TiO}_{2}-\mathrm{WO}_{3}$ IO. The
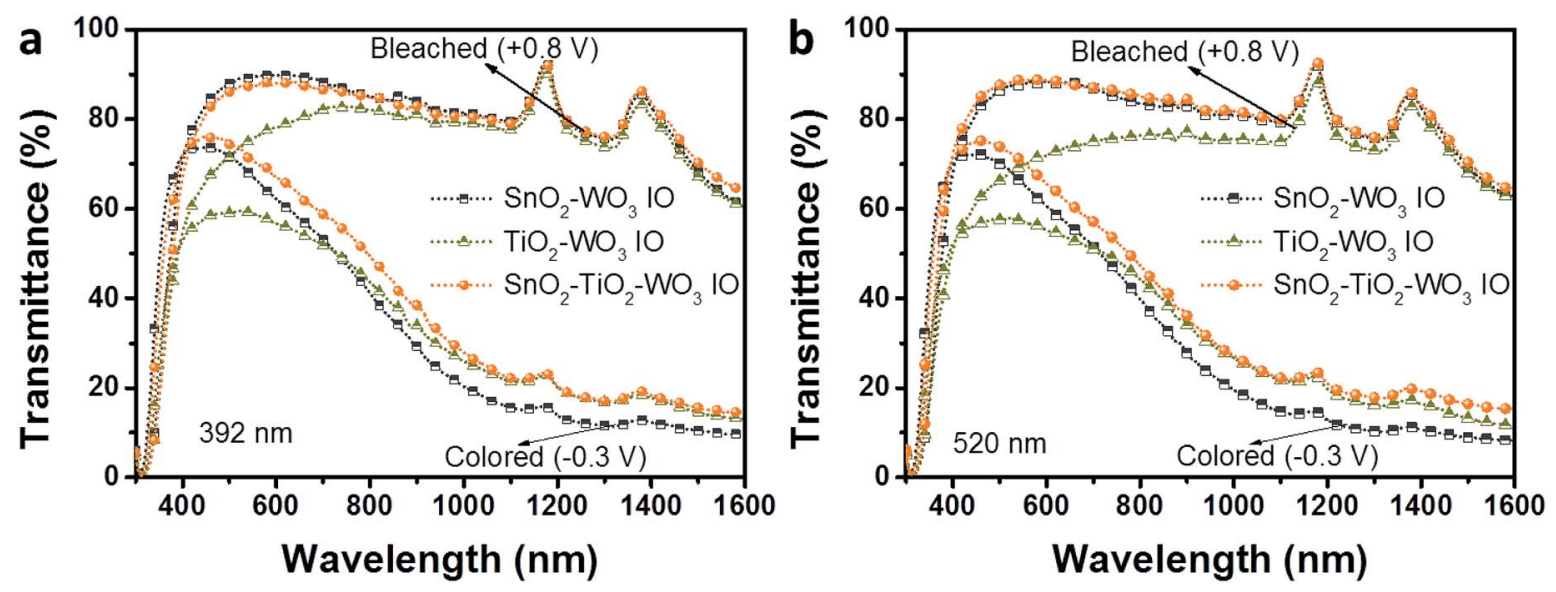

Fig. 6 UV-Vis-NIR spectra of $\mathrm{SnO}_{2}-\mathrm{WO}_{3}, \mathrm{TiO}_{2}-\mathrm{WO}_{3}$, and hybrid multi-layered $\mathrm{SnO}_{2}-\mathrm{TiO}_{2}-\mathrm{WO}_{3}$ IO nanostructure at bleached and colored state in $0.1 \mathrm{M} \mathrm{LiClO}_{4} / \mathrm{PC}$ electrolyte. Each UV-Vis-NIR spectrum is obtained from the average of three independent scans. 
$392 \mathrm{~nm} \mathrm{SnO}{ }_{2}-\mathrm{WO}_{3} \mathrm{IO}$ (Fig. 7c) shows 44.0, 69.7 and 51.2\% NIR modulation at 800, 1200 and $1600 \mathrm{~nm}$ respectively while $\mathrm{TiO}_{2}-$ $\mathrm{WO}_{3}$ IO shows $38.5,61.2$ and $47.5 \%$ NIR modulation at 800 , 1200 and $1600 \mathrm{~nm}$, respectively. For the hybrid multi-layered $\mathrm{SnO}_{2}-\mathrm{TiO}_{2}-\mathrm{WO}_{3} \mathrm{IO}$, the NIR modulation is recorded to be approximately 35.5, 63.6 and $49.6 \%$ at 800,1200 and $1600 \mathrm{~nm}$, respectively. For the samples with $520 \mathrm{~nm}$ initial PS opal size (Fig. 7d), the NIR contrast at 800, 1200 and $1600 \mathrm{~nm}$ is measured to be $43.8,70.7$ and $54.6 \%$ for $\mathrm{SnO}_{2}-\mathrm{WO}_{3} \mathrm{IO}, 32.1$, 60.6 and $51.2 \%$ for $\mathrm{TiO}_{2}-\mathrm{WO}_{3} \mathrm{IO}$, about $37.8,63.1$ and $49.1 \%$ for hybrid multi-layered $\mathrm{SnO}_{2}-\mathrm{TiO}_{2}-\mathrm{WO}_{3} \mathrm{IO}$, respectively. The results imply that the NIR modulation performance of $\mathrm{SnO}_{2}-$ $\mathrm{WO}_{3}$ IO structure is not influenced by the presence of an ultrathin $\mathrm{TiO}_{2}$ layer on $\mathrm{SnO}_{2}$ surface. In comparison with other reports, as-fabricated hybrid multi-layered $\mathrm{SnO}_{2}-\mathrm{TiO}_{2}-\mathrm{WO}_{3} \mathrm{IO}$ demonstrates comparable NIR modulation performance. The $\mathrm{Ag} / \mathrm{WO}_{3}$ nanowires reported by Zhou et al. showed approximately 59\% NIR modulation at $1100 \mathrm{~nm} ;{ }^{26}$ the bilayer $\mathrm{WO}_{3} \mathrm{IO}$ structure synthesized by Li et al. showed approximately $57.6 \%$ NIR modulation. ${ }^{40}$ The hybrid multi-layered $\mathrm{SnO}_{2}-\mathrm{TiO}_{2}-\mathrm{WO}_{3} \mathrm{IO}$ demonstrated 56.9 and $57.6 \%$ NIR modulation at $1100 \mathrm{~nm}$ for 392 and $520 \mathrm{~nm}$ initial PS opal sizes, respectively. Therefore, the hybrid multi-layered $\mathrm{SnO}_{2}-\mathrm{TiO}_{2}-\mathrm{WO}_{3}$ IO nanostructure developed in this study can provide two promising advantages in the smart windows technology: (1) large thermal radiation modulation and (2) high visible transparency. These advantages will be beneficial for the optimization of in-door lighting and thermal management.

The electro-optical response time in switching between the bleached and colored states of $\mathrm{SnO}_{2}-\mathrm{WO}_{3}, \mathrm{TiO}_{2}-\mathrm{WO}_{3}$ and hybrid multi-layered $\mathrm{SnO}_{2}-\mathrm{TiO}_{2}-\mathrm{WO}_{3}$ IO nanostructures is presented in Fig. 8a-c. The switching time is recorded to be approximately 21.6 and $21.1 \mathrm{~s}$ for the $\mathrm{SnO}_{2}-\mathrm{WO}_{3}$ and $\mathrm{TiO}_{2}-\mathrm{WO}_{3}$ IO, respectively. The switching time taken for the hybrid multilayered $\mathrm{SnO}_{2}-\mathrm{TiO}_{2}-\mathrm{WO}_{3} \mathrm{IO}$ is slightly longer, i.e. 24.5 s. Fig. 8d- f show the UV-Vis kinetics spectra of $\mathrm{SnO}_{2}-\mathrm{WO}_{3}, \mathrm{TiO}_{2}-\mathrm{WO}_{3}$ and hybrid multi-layered $\mathrm{SnO}_{2}-\mathrm{TiO}_{2}-\mathrm{WO}_{3}$ IO at $1033 \mathrm{~nm}$ for 750 reversible cycles. The electrochromic capacity of $\mathrm{SnO}_{2}-\mathrm{WO}_{3} \mathrm{IO}$ was found to reduce gradually over 750 cycles for both the bleached and colored states. It is estimated that the electrochromic performance reduces by 9.3 and $35.6 \%$ in the bleached and colored states, respectively. The electrochromic cycling stability of $\mathrm{TiO}_{2}-\mathrm{WO}_{3}$ IO shows improvement, with only 4.7 and $21.4 \%$ reduction in stability in the bleached and colored states respectively after 750 cycles. The novel hybrid multi-layered $\mathrm{SnO}_{2}-\mathrm{TiO}_{2}-\mathrm{WO}_{3}$ IO indicates the most significant improvement in EC stability. After 750 cycles, only 1.5 and $19.4 \%$ reduction in stability were recorded during the bleached and colored states, respectively. These results suggest that the presence of a thin $\mathrm{TiO}_{2}$ layer on $\mathrm{SnO}_{2}$ IO framework can significantly improve EC stability, and thus maintain the NIR modulation capability in hybrid multi-layered $\mathrm{SnO}_{2}-\mathrm{TiO}_{2}-\mathrm{WO}_{3}$ IO nanostructure.

It was reported that lithium accumulates as $\mathrm{OLi}$ in the $\mathrm{WO}_{3}$ films, but such phenomenon does not occur in $\mathrm{WO}_{3}-\mathrm{TiO}_{2}$ films. ${ }^{54}$ This ion-trapping may be the cause of degradation in the electrochromic performance during bleaching of $\mathrm{WO}_{3}$ based EC materials. Consequently, there is an improved EC stability in $\mathrm{TiO}_{2}-\mathrm{WO}_{3}$ structures. In the current study, the results in Fig. 8d-f indicate that the kinetics of ion extraction process (bleached state) is stable for over 750 cycles and only the ion insertion process (colored state) is affected. This implies that there is a reduction in the amount of $\mathrm{Li}^{+}$ions that can be intercalated into the $\mathrm{SnO}_{2}-\mathrm{WO}_{3}$ IO structure after each cycle. This may due to the crystallization of amorphous $\mathrm{WO}_{3}$ layer following the reversible cycling test as observed in a previous study. ${ }^{61}$ Arvizu et al. also reported that the addition of $\mathrm{Ti}$ significantly promoted the amorphous nature of the films and stabilized their electrochemical cycling performance and dynamic range for electrochromism. ${ }^{56}$ This could be the origin
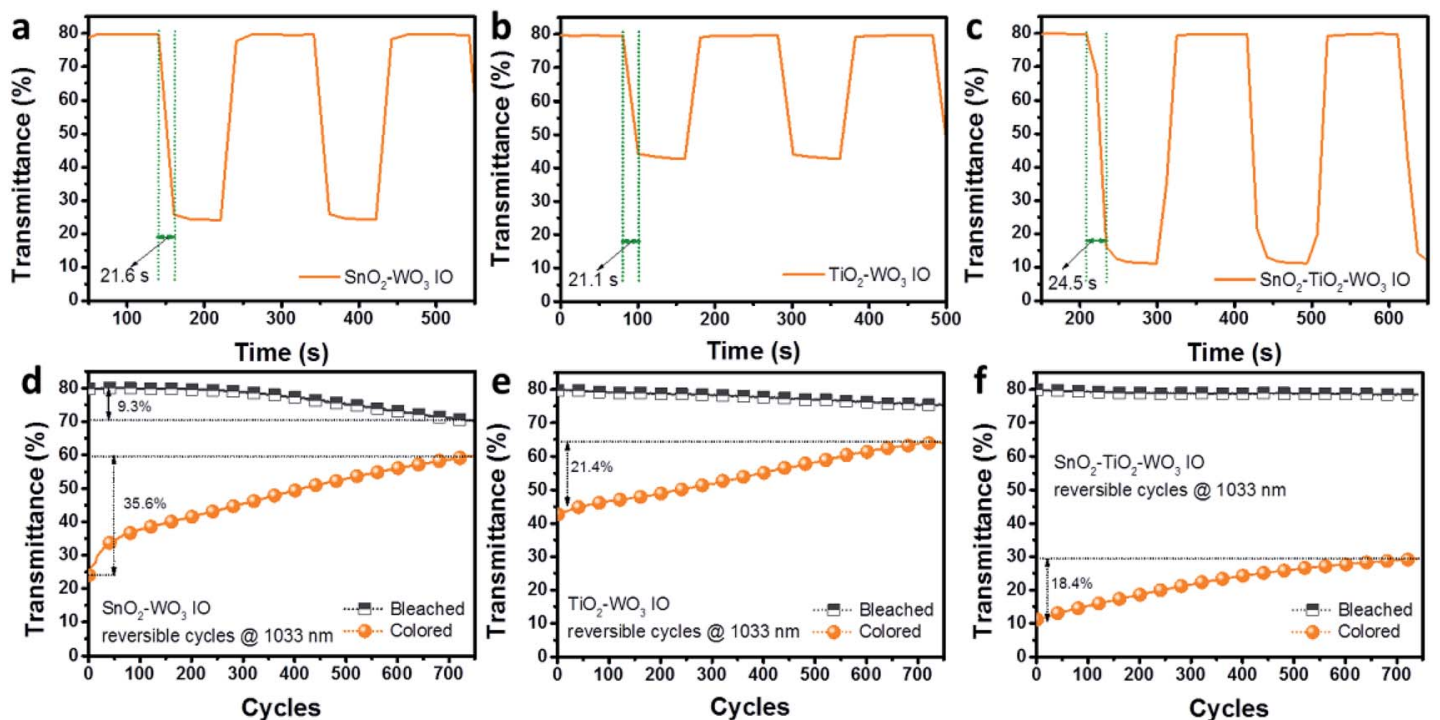

Fig. 8 Electro-optical response time between bleached and colored state (a-c) and kinetics stability (d-f) of $\mathrm{SnO}_{2}-\mathrm{WO}_{3}, \mathrm{TiO}_{2}-\mathrm{WO}_{3}$, and hybrid multi-layered $\mathrm{SnO}_{2}-\mathrm{TiO}_{2}-\mathrm{WO}_{3} \mathrm{IO}$ nanostructure for over 750 cycles. 
for the stable EC performance of as-fabricated hybrid multilayered $\mathrm{SnO}_{2}-\mathrm{TiO}_{2}-\mathrm{WO}_{3} \mathrm{IO}$.

\section{Conclusions}

In this work, a novel hybrid multi-layered $\mathrm{SnO}_{2}-\mathrm{TiO}_{2}-\mathrm{WO}_{3}$ inverse opal (IO) nanostructure is fabricated as an EC material for smart window application via electrodeposition of amorphous $\mathrm{WO}_{3}$ on a double-layered $\mathrm{SnO}_{2}-\mathrm{TiO}_{2}$ IO framework. The as-fabricated hybrid nanostructure integrates the high visible transparency of $\mathrm{SnO}_{2}$, effective near infrared (NIR) modulation of amorphous $\mathrm{WO}_{3}$, and durable EC cycling stability of $\mathrm{TiO}_{2}$. It is measured that the novel hybrid multi-layered $\mathrm{SnO}_{2}-\mathrm{TiO}_{2}-$ $\mathrm{WO}_{3} \mathrm{IO}$ is able to modulate up to $63.6 \%$ NIR radiation at the wavelength of $1200 \mathrm{~nm}$, while still allowing high visible transparency of approximately $67.2-88.0 \%$ and $67.0-74.4 \%$ in the bleached and colored states, respectively. Furthermore, it can also maintain approximately $82.6 \%$ of its NIR blockage capability after 750 reversible cycles. The smart window technology based on this hybrid multi-layered $\mathrm{SnO}_{2}-\mathrm{TiO}_{2}-\mathrm{WO}_{3}$ IO nanostructure $\mathrm{WO}_{3}$ can effectively assist in light and thermal management in buildings, thus reducing energy consumption of indoor lighting and air-conditioning.

\section{Conflicts of interest}

There are no conflicts to declare.

\section{Acknowledgements}

This research is supported by grants from the National Research Foundation, Singapore under its Campus of Research Excellence and Technological Enterprise (CREATE) Program.

\section{Notes and references}

1 C. G. Granqvist, Handbook of Inorganic Electrochromic Materials, Elsevier, 1st edn., 1995.

2 Electrochromic Materials and Devices, ed. R. J. Mortimer, D. R. Rosseinsky and P. M. S. Monk, Wiley-VCH, 2015.

3 C. G. Granqvist, Thin Solid Films, 2014, 564, 1-38.

4 A. Hjelm, C. G. Granqvist and J. M. Wills, Phys. Rev. B: Condens. Matter Mater. Phys., 1996, 54, 2436-2445.

5 G. A. de Wijs and R. A. de Groot, Phys. Rev. B: Condens. Matter Mater. Phys., 1999, 60, 16463-16474.

6 N. Bondarenko, O. Eriksson and N. V. Skorodumova, Phys. Rev. B: Condens. Matter Mater. Phys., 2015, 92, 165119.

7 C. A. Triana, C. G. Granqvist and G. A. Niklasson, J. Appl. Phys., 2015, 118, 024901.

8 H. Hamdi, E. K. H. Salje, P. Ghosez and E. Bousquet, Phys. Rev. B, 2016, 94, 245124.

9 H. Takeda and K. Adachi, J. Am. Ceram. Soc., 2007, 90, 40594061.

10 M. Layani, P. Darmawan, W. L. Foo, L. Liu, A. Kamyshny, D. Mandler, S. Magdassi and P. S. Lee, Nanoscale, 2014, 6, 4572-4576.
11 S. Y. Lee, J. Y. Kim, J. Y. Lee, H. J. Song, S. Lee, K. H. Choi and G. Shin, Nanoscale Res. Lett., 2014, 9, 294.

12 E. L. Runnerstrom, A. Llordés, S. D. Lounis and D. J. Milliron, Chem. Commun., 2014, 50, 10555-10572.

13 H. Ling, L. Liu, P. S. Lee, D. Mandler and X. Lu, Electrochim. Acta, 2015, 174, 57-65.

14 H. Ling, G. Ding, D. Mandler, P. S. Lee, J. Xu and X. Lu, Chem. Commun., 2016, 52, 9379-9382.

15 B. Zhou, W. Feng, G. Gao, G. Wu, Y. Chen and W. Li, Mater. Res. Express, 2017, 4, 115702.

16 J. S. E. M. Svensson and C. G. Granqvist, Thin Solid Films, 1985, 126, 31-36.

17 S. Morandi, G. Ghiotti, A. Chiorino and E. Comini, Thin Solid Films, 2005, 490, 74-80.

18 S. R. Bathe and P. S. Patil, Sol. Energy Mater. Sol. Cells, 2007, 91, 1097-1101.

19 A. Karuppasamy and A. Subrahmanyam, Thin Solid Films, 2007, 516, 175-178.

20 M. B. Johansson, B. Zietz, G. A. Niklasson and L. Österlund, J. Appl. Phys., 2014, 115, 213510.

21 H. Ling, J. Lu, S. Phua, H. Liu, L. Liu, Y. Huang, D. Mandler, P. S. Lee and X. Lu, J. Mater. Chem. A, 2014, 2, 2708-2717.

22 Y. Xin, H. Zhou, X. Ni, Y. Pan, X. Zhang, J. Zheng, S. Bao and P. Jin, RSC Adv., 2015, 5, 57757-57763.

23 V. R. Buch, A. K. Chawla and S. K. Rawal, Mater. Today: Proc., 2016, 3, 1429-1437.

24 M. Meenakshi, R. Sivakumar, P. Perumal and C. Sanjeeviraja, AIP Conf. Proc., 2016, 1731, 080070.

25 G. Cai, P. Darmawan, X. Cheng and P. S. Lee, Adv. Energy Mater., 2017, 7, 1602598.

26 K. Zhou, H. Wang, S. Zhang, J. Jiu, J. Liu, Y. Zhang and H. Yan, J. Mater. Sci., 2017, 52, 12783-12794.

27 J. Wang, E. Khoo, P. S. Lee and J. Ma, J. Phys. Chem. C, 2009, 113, 9655-9658.

28 J. Zhang, J.-p. Tu, G.-h. Du, Z.-m. Dong, Y.-s. Wu, L. Chang, D. Xie, G.-f. Cai and X.-l. Wang, Sol. Energy Mater. Sol. Cells, 2013, 114, 31-37.

29 C.-H. Lu, M. H. Hon, C.-Y. Kuan and I.-C. Leu, Jpn. J. Appl. Phys., 2014, 53, 06JG08.

30 H. R. Zeller and H. U. Beyeler, Appl. Phys., 1977, 13, 231-237.

31 S. Hashimoto and H. Matsuoka, J. Appl. Phys., 1991, 69, 933937.

32 A. A. Joraid, Curr. Appl. Phys., 2009, 9, 73-79.

33 M. M. El-Nahass, M. M. Saadeldin, H. A. M. Ali and M. Zaghllol, Mater. Sci. Semicond. Process., 2015, 29, 201-205. 34 G. Yuan, C. Hua, L. Huang, C. Defranoux, P. Basa, Y. Liu, C. Song and G. Han, Appl. Surf. Sci., 2017, 421, 630-635.

35 S.-L. Kuai, G. Bader and P. V. Ashrit, Appl. Phys. Lett., 2005, 86, 221110.

36 L. Liu, S. K. Karuturi, L. T. Su, Q. Wang and A. I. Y. Tok, Electrochem. Commun., 2011, 13, 1163-1165.

37 H.-N. Kim, H. Yoo and J. H. Moon, Nanoscale, 2013, 5, 42004204.

38 H. Zhang, G. Duan, G. Liu, Y. Li, X. Xu, Z. Dai, J. Wang and W. Cai, Nanoscale, 2013, 5, 2460-2468. 
39 P. Labouchere, A. K. Chandiran, T. Moehl, H. Harms, S. Chavhan, R. Tena-Zaera, M. K. Nazeeruddin, M. Graetzel and N. Tetreault, Adv. Energy Mater., 2014, 4, 1400217.

40 H. Li, J. F. Wang, G. Vienneau, G. B. Zhu, X. G. Wang, J. Robichaud, B.-L. Su and Y. Djaoued, $R S C A d v$., 2017, 7, 46406-46413.

41 H. Ling, L. P. Yeo, Z. Wang, X. Li, D. Mandler, S. Magdassi and A. I. Y. Tok, J. Mater. Chem. C, 2018, 6, 8488-8494.

42 J. P. Randin, J. Electron. Mater., 1978, 7, 47-63.

43 D. Chatzikyriakou, N. Krins, B. Gilbert, P. Colson, J. Dewalque, J. Denayer, R. Cloots and C. Henrist, Electrochim. Acta, 2014, 137, 75-82.

44 R. Todo, Y. Abe, M. Kawamura and K. H. Kim, ECS Trans., 2014, 58, 125-129.

45 V. Kotok, V. Kovalenko, V. Solovov and O. Yurlova, Technology Audit and Production Reserves, 2017, 3, 6.

46 K. Zhou, H. Wang, J. Liu and H. Yan, Int. J. Electrochem. Sci., 2018, 13, 7335-7346.

47 Z. Guo, Y. Chen and N. L. Lu, Multifunctional Nanocomposites for Energy and Environmental Applications, Wiley-VCH, Weinheim, 2018.

48 J. Yuan, B. Wang, H. Wang, Y. Chai, Y. Jin, H. Qi and J. Shao, Appl. Surf. Sci., 2018, 447, 471-478.

49 S. Sallard, T. Brezesinski and B. M. Smarsly, J. Phys. Chem. C, 2007, 111, 7200-7206.
50 K. D. Lee, J. Korean Phys. Soc., 2001, 38, 33-37.

51 R.-T. Wen, C. G. Granqvist and G. A. Niklasson, Nat. Mater., 2015, 14, 996.

52 S. R. Bathe and P. S. Patil, J. Phys. D: Appl. Phys., 2007, 40, 7423-7431.

53 J. M. O. R. de León, D. R. Acosta, U. Pal and L. Castañeda, Electrochim. Acta, 2011, 56, 2599-2605.

54 S. Hashimoto and H. Matsuoka, J. Electrochem. Soc., 1991, 138, 2403-2408.

55 Y.-C. Nah, A. Ghicov, D. Kim, S. Berger and P. Schmuki, J. Am. Chem. Soc., 2008, 130, 16154-16155.

56 M. A. Arvizu, C. A. Triana, B. I. Stefanov, C. G. Granqvist and G. A. Niklasson, Sol. Energy Mater. Sol. Cells, 2014, 125, 184189.

57 S. R. Bathe and P. S. Patil, J. Mater., 2014, 2014, 5.

58 G. Yang, PhD, National University of Singapore, 2015.

59 T. Kuroki, Y. Matsushima and H. Unuma, J. Asian Ceram. Soc., 2016, 4, 367-370.

60 M. D. Peng, Y. Z. Zhang, L. X. Song, L. N. Wu, Y. L. Zhang and X. F. Hu, Surf. Eng., 2017, 33, 305-309.

61 T. D. Nguyen, L. P. Yeo, T. C. Kei, D. Mandler, S. Magdassi and A. I. Y. Tok, Adv. Opt. Mater., 2019, 7, 1801389.

62 G. Cai, M. Cui, V. Kumar, P. Darmawan, J. Wang, X. Wang, A. Lee-Sie Eh, K. Qian and P. S. Lee, Chem. Sci., 2016, 7, 1373-1382. 